\section{Chronica Botanica}

THE first re-organized number of Chronica Botanica (4, No. 1, February 1938. Chronica Botanica Co., P.O. Box 8, Leyden) has recently been issued. This international journal, which deals with all branches of botany, horticulture, agronomy and silviculture, is now bimonthly, and the annual subscription has been reduced from fifteen to seven guilders. Most of the contributions are in English. The present number opens with a short account of the new Association for the Study of Systematics in Relation to General Biology (see also NATURE, 140, 163; 1937) by W. B. Turrill. Sixteen pages are devoted to correspondence and eleven pages to discussions. Notes from contributions of botanical interest to other journals occupy five pages. The reports of recent international congresses and announcements of forthcoming congresses are full and informative. Of outstanding interest is the section of news of more general interest from botanical and related institutes throughout the world. In fact, this section is, so far as we know, unique, and should prove of inestimable value to botanists, especially those engaged in research. The obituary announcements and notices are very full, and several portraits are included. Similarly, recent appointments and resignations are announced. This journal has achieved a world-wide reputation in a very short time. For this, the editor (Dr. F. Verdoorn) is to be congratulated; but it is well deserved. He and his advisory editors must be indefatigable in their efforts to glean botanical information from all parts of the world, resulting in a journal of plant science which all interested in plants will find of absorbing interest and great utility.

\section{The Tree Lover}

THe editorial in the Tree Lover (vol. 2 , No. $21 ; 1937$ ) deals with several points in connexion with trees and forestry principles in the opening words "More and more do Trees become 'news' and the claims of forestry find mention in the Press". This is a position which NATURE realized more than a decade ago and has since kept in close touch with this important subject with the object of educating a public who had completely lost all 'forest sense'. The editor perforce alludes to the appalling dust bowls in process of creation in the United States and Canada. But he is equally concerned over the threatened final demolition of Milton's Elm, 500 years in age, at Chalfont St. Giles, the remaining 12-foot stump being in danger owing to the expressed intention of widening the road. As the editor states, "The crisis of Milton's Elm is typical of what is happening all over the Country. One can only hope that ere long there will be a reaction from the ruthless cult of speed". He mentions the several bodies who are taking up the campaign against the increasing vandalism of the builder and road-maker. This autumn quarterly number deals with such matters as Gloucestershire woodlands, Whiligh and its trees, evolution of the moor, and the Royal Gardens of Sandringham and Windsor.

\section{Medical Research in South Africa}

THE annual report for 1936 of the South African Institute for Medical Research, Johannesburg, of which Sir Spencer Lister is director, gives an account of the routine and research work pursued there. The bacteriology and epidemiology of pneumonia in local mine natives are continuously studied by Dr. Ordman. The use of prophylactic pneumonia vaccine is increasing in the mines, and a number of satisfactory results continue to be recorded. Routine specimens examined for plague infection numbered 144 from human sources and 1,908 from animals, positive results being obtained in 49 human cases and in 5 rodents. Strains of the plague bacillus maintained in the laboratory have been found by Dr. Pirie to undergo a steady diminution in virulence. Much work has been done by Dr. Mavrogordato upon mine dust and its relation to silicosis in miners' lungs, and Mr. Rabson has determined the size of the particles present in the dust. Ninety per cent of the mass of dust is found to consist of particles of $4 \mu$ and less. Malaria research and the prevalence and species of mosquitos in certain districts, the venoms of snakes, and researches on tumour agents, are some of the other subjects that have been investigated.

\section{The Management Library}

The Management Library which was opened to general use by industry in June 1932 has issued a report on progress in the five years ended June 30, 1937. 1,000-1,500 books are now out on loan at a time, or a total of 15,000 volumes in the year, and 1,250 copies of the monthly review are issued to members, subscribers to which come from France, Belgium, Holland, Switzerland, Sweden, Norway, India, Japan and elsewhere. The reviews are now framed to outline the chapter headings, evaluate new contributions to knowledge and to indicate the departments or persons in industry to whom the book is of special value. Although serving various institutions and associations, the Library has no direct affiliation with any other organization. Income from subscriptions has grown from $\mathfrak{£ 1 5 0}$ in the first six months to $£ 1,000$ in 1936 and $£ 684$ in the first six months of 1937 .

\section{Education in the U.S.S.R.}

According to the Soviet Union Year Book Press Service the educational services budget this year shows an increase of more than thirty per cent compared with that of last year $(13,916$ million roubles), and 3,613 new schools are to be built to provide accommodation for more than a million pupils, namely, 663,740 in rural areas, 518,950 in urban areas, and 35,000 children of railway workers scattered throughout the country. Special schools for railway workers' children already accommodate more than a million. The total urban schools attendance is $8,800,000$, the rural schools $21,200,000$. The accommodation to be provided by the new schools will therefore increase the capacity of the present urban schools by 6 per cent and that of the other schools by 3 per cent.

\section{(Continued on $p .469$ )}

